\title{
Consistent DNA Hypermethylation Patterns in Laryngeal Papillomas
}

\author{
${ }^{1}$ Josena K Stephen, ${ }^{1}$ Kang Mei Chen, ${ }^{2}$ Veena Shah, ${ }^{1}$ Vanessa G Schweitzer, ${ }^{1}$ Glendon Gardner \\ ${ }^{3}$ Michael S Benninger, ${ }^{1}$ Maria J Worsham
}

\author{
${ }^{1}$ Department of Otolaryngology, Head and Neck Surgery and Research Division, Henry Ford Hospital, Detroit, MI 48202, USA
}

2Department of Pathology, Henry Ford Hospital, Detroit, MI 48202, USA

${ }^{3}$ Head and Neck Institute, Cleveland Clinic, Cleveland, OH 44195, USA

Correspondence: Maria J Worsham, Director of Research, Department of Otolaryngology/Head and Neck Research Professor, Department of Pathology, Wayne State School of Medicine, Henry Ford Hospital, 1 Ford Place, 1D, Detroit MI 48202, USA, Phone: 313-874-3350, Fax: 313-874-1079, e-mail: mworshal@hfhs.org

\begin{abstract}
Introduction: This study examined the contribution of promoter hypermethylation to the pathogenesis of respiratory papillomatosis (RP), including recurrences (RRP) and progression to squamous cell carcinoma (SSC).

Materials and methods: A retrospective cohort of 25 laryngeal papilloma cases included 21 RRP, two of which progressed to SCC. Aberrant methylation status was determined using the multigene (22 tumor suppressor genes) methylation-specific multiplex ligationdependent probe amplification assay and confirmed using methylation specific PCR.

Results: Twenty genes had altered DNA methylation in 22 of 25 cases. Aberrant methylation of CDKN2B and TIMP3 was most frequent. Promoter hypermethylation of $B R C A 2, A P C, C D K N 2 A$ and $C D K N 2 B$ was detected in 2 RRP cases with subsequent progression to SCC. Of the 25 cases, 22 were positive for HPV-6, 2 for HPV-11 and 1 for HPV-16 and 33.

Conclusion: Consistent aberrant methylation of multiple tumor suppressor genes contributes to the pathogenesis of laryngeal papillomas. Persistent aberrant DNA methylation events in 2 RRP cases that progressed to cancer indicate an epigenetic monoclonal progression continuum to SCC.
\end{abstract}

Keywords: Laryngeal papillomas, recurrent papillomas, DNA methylation, squamous cell carcinoma.

\section{INTRODUCTION}

Papilloma is a benign exophytic neoplasm of epithelium on a connective tissue core. ${ }^{1}$ Respiratory papillomatosis (RP) is a benign disease characterized by unregulated growth of wartlike neoplasms of the larynx, trachea, and bronchi with propensity for recurrences (RRP). In the larynx, the stratified squamous variety is the commonest form of papilloma. ${ }^{1}$ The histopathology is similar at all ages. Laryngeal papillomas usually run a benign but recurrent course. In the spontaneous transformation of RP or RRP to squamous cell carcinoma (SCC), a progression continuum to malignancy may not be histologically and clinically apparent, making these lesions difficult to diagnose early in the course of the transformation of the disease. Only a small percentage of RRP cases actually progress to malignancy. ${ }^{2,3}$ Transformation of laryngeal papillomas to malignant neoplasms range from 1.25 to $42.9 \%{ }^{4,5}$
The human papilloma virus (HPV), which is associated with genital papillomas, has also been associated with laryngeal papillomas as an etiologic agent, ${ }^{6-8}$ particularly HPV types 6 and $11 .{ }^{9}$ Studies on HPV typing in benign laryngeal papillomas have demonstrated an association of HPV type 11 with a more aggressive course of the disease. ${ }^{10,11}$ According to Lele et al, ${ }^{12}$ HPV-11 infection may be an early event in progression of RRP to carcinoma.

Epigenetics is the regulation of changes in gene expression by mechanisms that do not involve changes in DNA sequence. Establishment and maintenance of epigenetic control (gene silencing) has several aspects, which include promoter region hypermethylation, methylbinding proteins, DNA methyltransferases, histone deacetylases and chromatin state. Aberrant methylation of $\mathrm{CpG}$ islands is a hallmark of human cancers and is found early during carcinogenesis. ${ }^{13}$ Epigenetic events of DNA 
hypermethylation contribute to RRP pathogenesis, some of which are initiating clonal alterations in the recurrence continuum. ${ }^{14}$ Aberrant methylation of $C D K N 2 B$ and $A P C$ genes was most frequent, followed by $C D K N 2 A, T I M P 3$, VHL, DAPK1, HIC1, and GSTP $1 .{ }^{14}$

Recurrent genomic aberrations are good indicators of genes that are causally associated with transformation, cancer development or progression. To asses the contribution of promoter methylation in RP tumorigenesis, we investigated an expanded retrospective cohort of 25 papilloma cases with an initial laryngeal papilloma biopsy between the years 1994 and 2004, with follow-up for subsequent transformation to carcinoma in situ, or SCC through August 2009. Aberrant promoter methylation of 22 unique methylation-prone tumor suppressor genes was evaluated using the high-throughput methylation-specific multiplex ligation dependent probe amplification (MS-MLPA) assay (41 gene probes, 35 unique genes, including control probes) and methylation specific PCR (MSP).

\section{MATERIALS AND METHODS}

\section{Patient Cohort}

The laryngeal papilloma cohort of 25 subjects (21 Caucasian American $\{\mathrm{CA}\}$ and 4 African American $\{\mathrm{AA}\}$ ), comprised 5 females and 20 males, all adult onset, ranging in age from 19 to 73 years and 1 female juvenile onset (1-year-old). Of the 25 cohort subjects, 4 were nonrecurrent papillomas (RP) and 21 were RRP. Of the 21 RRP cases, DNA from multiple biopsies were available from $15 \mathrm{RRP}$ for methylation assays.
The number of recurrent biopsies ranged from 2 to 22 biopsies from the initial primary biopsy (follow-up through August 2009). The interval between biopsies for these subjects ranged from 23 days (shortest) to 102 months (longest).

When the primary RP biopsy was not available for DNA analysis, the first available RP became the reference biopsy. Of the 25 cases, there were 19 primary and 6 reference biopsies. Primary and reference biopsies included lesions with benign squamous papilloma ( 16 cases), mild dysplasia ( 5 cases), moderate dysplasia (1 case), and moderate/severe dysplasia (3 cases). Lesions with mixed moderate and severe dysplasia were classed separately from progression lesions of purely severe dysplasia, carcinoma in situ (CIS), and SCC.

\section{DNA Extraction}

Whole 5 micron formalin-fixed tissue sections or microdissected papilloma tissue, and subsequent transformation to severe dysplasia, CIS, or SCC lesions ( 2 cases), were processed for DNA extraction as previously described. ${ }^{15,16}$

\section{HPV Detection}

HPV status was identified using the Linear Array HPV Genotyping kit (Roche, Indianapolis, IN) in all cases. PCR using HPV type primers for HPV 6, 11, 16, 31 and 33 especially designed to amplify less than 120 base pair DNA fragment lengths (Table 1) was also used to detect HPV status in some cases.

Table 1: HPV PCR primers

\begin{tabular}{|c|c|c|c|c|c|}
\hline GenBank accession \# & $\begin{array}{l}\text { Start to end } \\
\text { (bp) }\end{array}$ & Forward and reverse (5' to $\left.3^{\prime}\right)$ & $\begin{array}{c}\text { PCR } \\
\text { length }\end{array}$ & $\begin{array}{l}\text { Annealing } \\
\text { temp }\end{array}$ & Regions \\
\hline AF335604.1: HPV6-137 & 1080 to 1217 & $\begin{array}{l}\text { F: ACATGCGTCATGTGGAAGAG } \\
\text { R: AGGCGATAACCCAAAGTTCC }\end{array}$ & 137bp & $52^{\circ} \mathrm{C}$ & L1 \\
\hline M14119.1: HPV 11-182 & 578 to 760 & $\begin{array}{l}\text { F: CCTGCAGCCTCCTGACCCTGT } \\
\text { R: CTCCGTCTGTGCACTCCACAA }\end{array}$ & 182bp & $60^{\circ} \mathrm{C}$ & E7 \\
\hline M14119.1: HPV 11-230 & 291 to 521 & $\begin{array}{l}\text { F: TGCAGCGTGTGCCTGTTGCTT } \\
\text { R: AGCAACGACCCTTCCACTGGT }\end{array}$ & $230 \mathrm{bp}$ & $60^{\circ} \mathrm{C}$ & E6 \\
\hline NC001526.1: HPV 16-101 & 497 to 597 & $\begin{array}{l}\text { F: TGGACCGGTCGATGTATGT } \\
\text { R: CATATATTCATGCAATGTAGGTGTA }\end{array}$ & 101bp & $54^{\circ} \mathrm{C}$ & E6 \& E7 \\
\hline NC001526.1: HPV 16-173 & 425 to 597 & $\begin{array}{l}\text { F: AAGCCACTGTGTCCTGAAGAA } \\
\text { R: CATATATTCATGCAATGTAGGTGTA }\end{array}$ & 173bp & $54^{\circ} \mathrm{C}$ & E6 \& E7 \\
\hline NC001526.1: HPV 16-258 & 382 to 640 & $\begin{array}{l}\text { F: AATACAACAAACCGTTGTGTGATT } \\
\text { R: CAGTAGAGATCAGTTGTCTCTGGTTGC }\end{array}$ & $258 b p$ & $58^{\circ} \mathrm{C}$ & E6 \& E7 \\
\hline J04353.1: HPV 31-124 & 3861 to 3962 & $\begin{array}{l}\text { F: TTTGCTTTGCTTTTGTGTGCTAC } \\
\text { R: TGGAGAGGTTGCAATAACCCATA }\end{array}$ & $124 b p$ & $52^{\circ} \mathrm{C}$ & E5 \\
\hline M12732.1: HPV 33-149 & 424 to 572 & $\begin{array}{l}\text { F: TGTCAAAGACCTTTGTGTCCTC } \\
\text { R: GGCGTTTTTACACGTCACAG }\end{array}$ & 149bp & $54^{\circ} \mathrm{C}$ & E6 \\
\hline
\end{tabular}


The Methylation-Specific Multiplex Ligation Dependent Probe Amplification (MS-MLPA) Assay

The Multiplex Ligation-Dependent Probe Amplification assay allows for the relative quantification of approximately 41 different DNA sequences in a single reaction requiring only $20 \mathrm{ng}$ of human DNA. The standard use of the technique to observe quantitative changes in copy number (MLPA) ${ }^{16,17}$ and adaptation of MLPA to detect aberrant methylation (MS-MLPA) has been detailed elsewhere. ${ }^{14,16,18}$

\section{Bisulfite Modification and Methylation-Specific Polymerase (MSP) Chain Reaction Assay}

Genomic DNA (100 ng) from formalin-fixed paraffin embedded papilloma tissue and control universal methylated DNA (Chamicon International, Inc) and control unmethylated DNA (normal genomic DNA) were modified using the EZ DNA methylation gold kit (Zymo Research, Orange, CA) during which methylated DNA is protected and unmethylated cytosine is converted to uracil. ${ }^{18}$ The modified DNA served as a template using primers specific for the methylated or modified unmethylated sequences (Table 2). MSP amplification was performed using $3 \mathrm{ul}$ of bisulfite modified DNA in a final volume of $25 \mathrm{ul} \mathrm{PCR} \mathrm{mix}$ containing 1X PCR buffer, $2.5 \mathrm{mM}$ dNTP, $1 \mathrm{mM} \mathrm{MgCl} \mathrm{Mg}_{2}$ and $1 \mathrm{U}$ Amp gold Taq DNA polymerase, $0.5 \mathrm{uM}$ primer followed by 38 cycles at $95^{\circ} \mathrm{C} 45$ seconds, $62^{\circ} \mathrm{C} 45$ seconds, $72^{\circ} \mathrm{C} 1$ min. ${ }^{18}$ The resultant PCR products were separated on $2 \%$ agarose gel stained with ethidium bromide and visualized under UV illumination.

\section{RESULTS}

Promoter hypermethylation by MS-MLPA or by MSP was recorded in 22 of 25 cases. Twenty of 22 tumor suppressor genes in the multi-gene panel had altered DNA methylation in at least one RP biopsy. Aberrant methylation of TIMP3 and $C D K N 2 B$ genes was most frequent, occurring in 13 of 22 and 11 of 22 cases, respectively, followed by $C D K N 2 A$, $A P C$ and $V H L$ genes in 9 of 22 cases, and TP73, GSTP1, HIC1, MLH1 and DAPK1 genes in 5 of 22 cases.

Of the 21 RRP cases, multiple biopsies were examined for aberrant methylation in 15 cases. Identical abnormally methylated genes were found in recurrent biopsies of 5 of 15 RRP cases and an aberrantly methylated $C D K N 2 B$ gene linked all 5 cases (cases $4,7,11,12,13) .{ }^{14}$ MSP confirmed aberrant methylation of $C D K N 2 B$ in RRP cases $4,7,11$ and 12 in multiple recurrent biopsies (MSP for Case 13 was not performed).

Progression to SCC occurred in RRP cases 1 and 5 (Table 3). In RRP case 1, the papillomas in biopsies 1 through 3 were located on both the left and right vocal folds. Subsequent dysplastic papillomas were located on both left and right true as well as false vocal cords (biopsies 4-6, Table 3). For case 5, the laryngeal subsite for the reference biopsy and the subsequent recurrent lesions was the right true vocal cord.

In RRP case 1, aberrant methylation of $B R C A 2$ and $A P C$, identified in the primary biopsy, was also present in the recurrent severe dysplasia, CIS, and recurrent SCC (Table 3). MSP confirmed MS-MLPA methylation of $B R C A 2$ (biopsy 1), APC (biopsy 4), GSTP1 (biopsy 6), and

Table 2: Methylation and unmethylation MSP primer sequences for laryngeal papillomas

\begin{tabular}{|c|c|c|c|c|}
\hline Gene & & Methylation specific primers & Unmethylation specific primers & Product size \\
\hline \multirow{2}{*}{ BRCA2 } & Forward & 5'-GACGGTTGGGATGTTTGATAAGG & 5'-AGGGTGGTTTGGGATTTTTAAGG & M - 337bp \\
\hline & Reverse & 5'-АATCTATCСССТСАСGСТTCTCC & 5'-ТСАСАСТTСТСССААСАAСАACC & $U-250 b p$ \\
\hline \multirow{2}{*}{$A P C$} & Forward & 5'-TATTGCGGAGTGCGGGTC & 5'-GTGTTTTATTGTGGAGTGTGGGTT & M - 97bp \\
\hline & Reverse & 5'-TCGAAGAACTCCCGACGA & 5'-CСAATCAACAAACTCCСАACAA & $U-108 b p$ \\
\hline \multirow[t]{2}{*}{ GSTP1 } & Forward & 5'-TTCGGGGTGTAGCGGTCGTC & 5'-GATGTTTGGGGTGTAGTGGTTGTT & $M-91 b p$ \\
\hline & Reverse & 5'-GCCCCAATACTAAATCACGACG & 5'-ССАССССААТАСТАAАТСАСАACA & $U-97 b p$ \\
\hline \multirow[t]{2}{*}{$C D K N 2 A^{A R F}$} & Forward & 5'-TATCGAGTTTTTTGTGTTTAGTCC & 5'-TATTGAGTTTTTTGTGTTTAGTTT & $M-112 b p$ \\
\hline & Reverse & 5'-AACGACCAACAAAAAAAAAAAACG & 5'-CAACAAAAAAAAAACAACCAAC & $U-124 b p$ \\
\hline \multirow[t]{2}{*}{$C D K N 2 B^{\dagger}$} & Forward & 5'-GAAGGTGCGATAGTTTTTGGAAGTCGGCGC & 5'-TGGAGAAGGTGTGATAGTTTTTGGAAGTTGGTGT & M - 160bp \\
\hline & Reverse & 5'-GACGATCTAAATTCCAACCCCGATCCGCCG & 5'-CATCAACAATCTAAATTCCAACCCCAATCCACCA & $U-169 b p$ \\
\hline
\end{tabular}


$C D K N 2 A$ (biopsies 5 and 6). MSP and MS-MLPA were concordant for lack of methylation $A P C, G S T P 1$, and $C D K N 2 A$, and $C D K N 2 B$ (Table 3).

In RRP case 5, aberrant methylation of $B R A C 2, A P C$ and $C D K N 2 A$ in the reference papilloma biopsy and $C D K N 2 B$ in biopsy 2 were also identified in the subsequent progression lesions (Table 3, Fig. 1). MSP confirmed MSMLPA methylation of $A P C$ (biopsies 1 and 4) and $C D K N 2 A$ (biopsies 1 to 3). MSP also confirmed absence of methylation for CDKN2B (biopsies 1 and 4) and GSTP1 (biopsies 2 to 4 ) detected by MS-MLPA (Fig. 2).

HPV was identified in all 25 cases by either the Roche Linear Array and/or by PCR. Among the $21 \mathrm{HPV}$ positive RRP cases, 18 were HPV-6, 1 was HPV-16 and 33 (Case 1), and 2 were HPV-11 positive (Cases 5 and 7). The remaining $4 \mathrm{RP}$ were positive for HPV-6. Case 1 was positive for HPV16 and 33 in the primary SCC but was not detected in the recurrent SCC lesion. HPV-6 status in case 1, biopsy 5, detected by the Roche Linear Array was not confirmed by PCR. Case 5 biopsies were negative for HPV by the Roche Linear Array. However, HPV-11 by PCR, using two different primer sets, identified HPV-11 only in the first (reference) biopsy and confirmed lack of HPV for biopsies 2 through 4 (Table 3 ).

\section{DISCUSSION}

Recurrent genomic aberrations are good indicators of genes that are causally associated with cancer development, transformation or progression. Our previous studies ${ }^{14,16}$ have demonstrated that epigenetic events of DNA hypermethylation underlie the pathogenesis of benign sinonasal and recurrent laryngeal papillomas, establishing a monoclonal origin for RRP. Our current findings reiterate consistent DNA hypermethylation events in a larger cohort of laryngeal papillomas and trace a progression continuum to SCC. The results further support a monoclonal progression for malignant transformation in 2 RRP cases.

Spontaneous transformation of RP to laryngeal squamous cell carcinoma (LSCC) is not easily characterized by a histologic progression through dysplasia over time, making these lesions difficult to diagnose histologically and clinically early on in the course of the transformation of the disease. Several studies have attempted to identify markers that can predict which patients with RP are at a higher risk

Table 3: Epigenetically linked progressive laryngeal cases

\begin{tabular}{|c|c|c|c|c|c|c|c|c|c|}
\hline RRP & Lesion type & Biopsy & $\begin{array}{c}\text { Time } \\
\text { interval }\end{array}$ & BRCA2 & APC & CDKN2A & CDKN2B & $\begin{array}{c}\text { HPV } \\
\text { (Roche) }\end{array}$ & $\begin{array}{l}\text { HPV } \\
(P C R)\end{array}$ \\
\hline \multirow[t]{7}{*}{ Case 1} & Squamous papilloma & 1 & Primary & $M^{*}$ & $\mathrm{M}^{+}$ & $U^{*}$ & $U^{*}$ & 16 & 16 \\
\hline & $\begin{array}{l}\text { Squamous papilloma with } \\
\text { severe dysplasia }\end{array}$ & 2 & 4 months & $\mathrm{M}^{+}$ & $M^{+}$ & $U^{*}$ & $U$ & & 16 \\
\hline & Primary SCC, Block 1 tumor & 3Т & 6 months & $\mathrm{M}^{+}$ & $U^{*}$ & $U^{*}$ & $U$ & & 16 and 33 \\
\hline & Primary SCC, Block 1 dysplastic papilloma & $3 P$ & 6 months & $\mathrm{M}^{+}$ & $\mathrm{M}^{+}$ & $U^{*}$ & $U$ & & 16 \\
\hline & Recurrent severe dysplasia & 4 & 50 months & $\mathrm{M}^{+}$ & $M^{*}$ & $\mathrm{M}^{+}$ & $U^{*}$ & Neg & Neg \\
\hline & Carcinoma in situ & 5 & 51 months & $\mathrm{M}^{+}$ & $\mathrm{M}^{+}$ & $M^{*}$ & $U^{*}$ & 6 & Neg \\
\hline & Recurrent SCC & 6 & 53 months & $\mathrm{M}^{\dagger}$ & $\mathrm{M}^{+}$ & $M^{*}$ & U, NR by MSP & Not & Neg \\
\hline \multirow[t]{4}{*}{ Case 5} & $\begin{array}{l}\text { Squamous papilloma with moderate to } \\
\text { severe dysplasia }\end{array}$ & 1 & Reference & $\mathrm{M}^{+}$ & $M^{*}$ & $M^{*}$ & $U^{*}$ & $\mathrm{Neg}$ & 11 \\
\hline & $\begin{array}{l}\text { Squamous papilloma with mild to } \\
\text { moderate dysplasia }\end{array}$ & 2 & 2 months & $\mathrm{M}^{+}$ & $\mathrm{M}^{+}$ & $M^{*}$ & M & $\mathrm{Neg}$ & Neg \\
\hline & Primary SCC & 3 & 9 months & $\mathrm{M}^{+}$ & $\mathrm{M}^{+}$ & $M^{*}$ & M & Neg & Neg \\
\hline & Carcinoma in situ & 4 & 11 months & $\mathrm{M}^{\dagger}$ & $M^{*}$ & $\mathrm{M}^{+}$ & $U^{*}$ & Neg & Neg \\
\hline
\end{tabular}

RRP = Recurrent respiratory papilloma

SCC $=$ Squamous cell carcinoma

$\mathrm{M}=$ Methylation detected by MS-MLPA only

$\mathrm{M}^{\dagger}=$ Methylation detected by MSP only

$\mathrm{M}^{*}=$ MS-MLPA methylation confirmed by MSP

$U=$ Unmethylated by MS-MLPA only

$\mathrm{U}^{*}=$ Unmethylated by MS-MLPA and MSP

$N R=$ No reaction by MSP because of insufficient DNA

$\mathrm{Neg}=$ Negative for HPV 


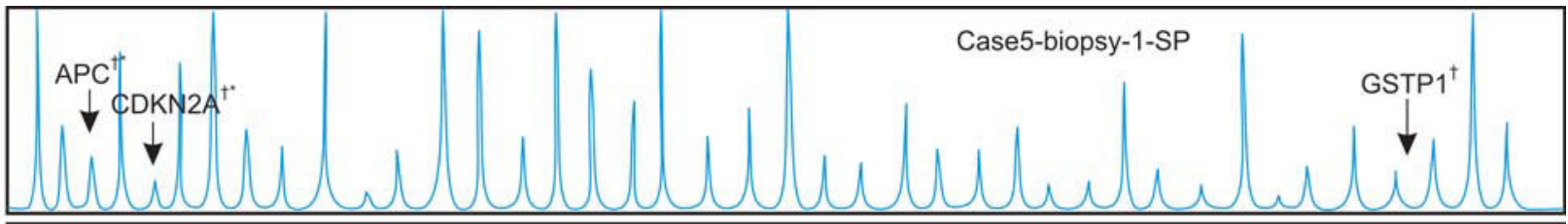

B
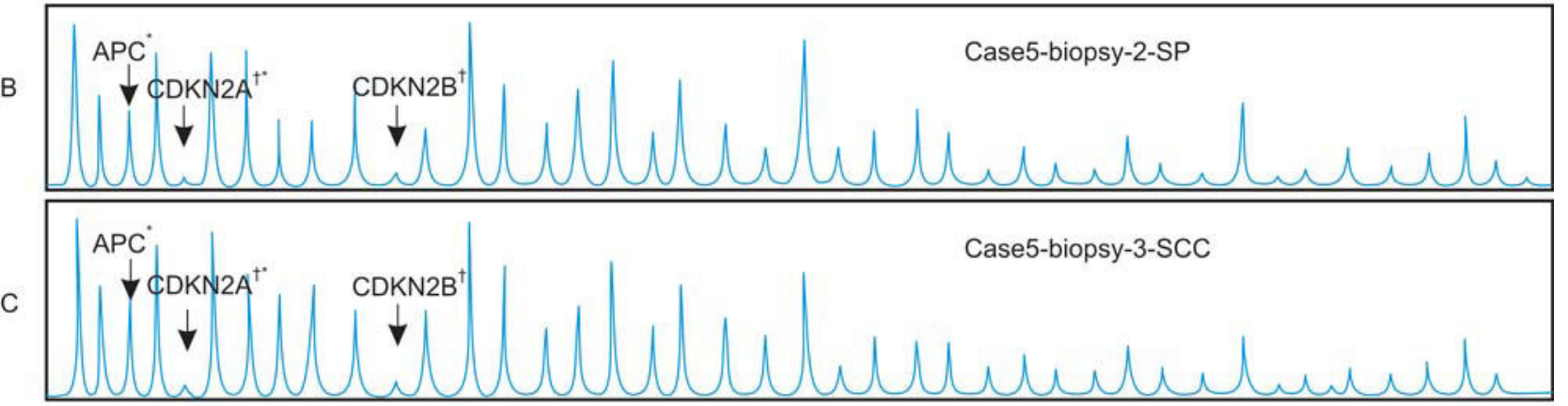

D

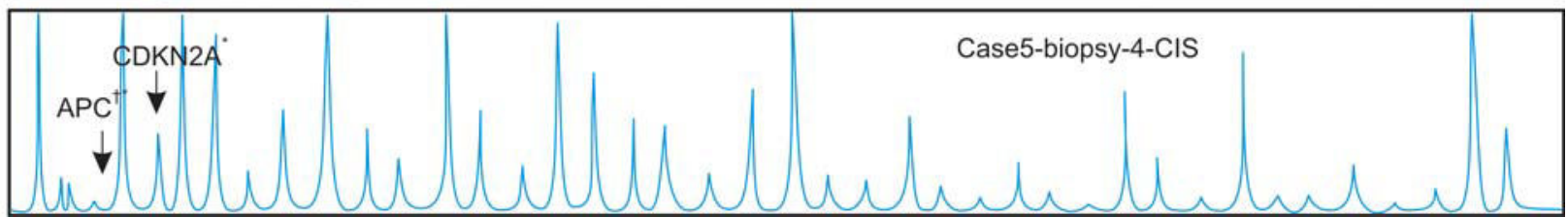

Fig. 1: Case 5 results of MS-MLPA. Note methylation of $A P C$ by MS-MLPA with confirmation by MSP $\left(A P C^{\dagger}\right)$ in biopsies 1 and 4 . MSP alone detected $A P C$ methylation in biopsies 2 and $3\left(A P C^{*}\right)$. Note methylation of $C D K N 2 A$ by MS-MLPA with confirmation by MSP $\left(C D K N 2 A^{\dagger *}\right)$ in biopsies 1, 2 and 3. MSP alone detected CDKN2A methylation in biopsy 4 (CDKN2A*). Note methylation of CDKN2B in biopsies 2 and 3 and GSTP1 in biopsy 1 by MS-MLPA only $\left(C D K N 2 B^{\dagger}, G S T P 1^{\dagger}\right)$ (SP-squamous papilloma, CIS-carcinoma in situ, SCC-squamous cell cancer)

for more frequently recurring aggressive disease or malignant transformation. However, results in both benign laryngeal lesions (papillomatosis) and malignant lesions have not been definitive. ${ }^{12,19-22}$ Currently, there are no biomarkers of aggressive RP that predict benign recurrence and transformation to malignancy from RP.

In this study, TIMP 3 was the most frequently methylated gene (13/22 cases), followed by $C D K N 2 B, C D K N 2 A, A P C$, VHL, TP73, GSTP1, HIC1, MLH1 and DAPK 1. TIMP3 induces apoptosis, ${ }^{23}$ inhibits angiogenesis,${ }^{24}$ impedes cell migration, ${ }^{25}$ and is a physiological regulator of inflammation. ${ }^{26}$ Promoter methylation of TIMP3 has been observed in many tumor types ${ }^{27,28}$ and is involved in the genesis of esophageal adenocarcinoma notably during progression from dysplasia to carcinoma. ${ }^{29,30}$

$C D K N 2 B$ and $C D K N 2 A$ were hypermethylated in 11 of 22 and 9 of 22 cases, respectively. Genetic alterations in $C D K N 2 A$ and $C D K N 2 B$ genes, which map to 9p21, have been linked to malignant progression in HNSCC. ${ }^{31-33}$ Inactivation of the CDKN2B (p15) and CDKN2A (p14 and $p 16)$ genes at the genomic and epigenetic level is a frequent event in human oral SCCs and in HNSCC. ${ }^{17,34,35}$ One study reported aberrant methylation of $C D K N 2 B(p 15)$ and $C D K N 2 A$ (p16) in more than $50 \%$ of the oral squamous cell carcinomas (OSCC). ${ }^{36}$ The presence of aberrant methylation of $p 15$ and $p 16$ in precancerous oral tissues ${ }^{35}$ implicates methylation of $p 15$ and $p 16$ as early events in the pathogenesis of oral lesions. In undifferentiated nasopharyngeal carcinoma (NPC), preferential methylation of $C D K N 2 B$ has been shown to be a useful tumor marker for NPC. ${ }^{37}$ In case 5, aberrant methylation of $C D K N 2 A$ in the reference biopsy and $C D K N 2 B$ in biopsy 2 and subsequent transformation biopsies occurs as an early event and provides evidence of a monoclonal progression continuum to SCC.

Hypermethylation of the $A P C$ gene was detected in multiple biopsies in 8/15 RRP cases and 1 RP. $A P C$ (adenomatosis polyposis coli) is a tumor suppressor gene originally implicated in colon cancer. Genetic and epigenetic alterations in this gene have since been recognized in other malignancies including OSCC, gastric cancers and esophageal adenocarcinomas. Uesugi et al. ${ }^{38}$ previously, reported mutations and/or deletions of $A P C$ in primary OSCC and suggested that loss of $A P C$ function 


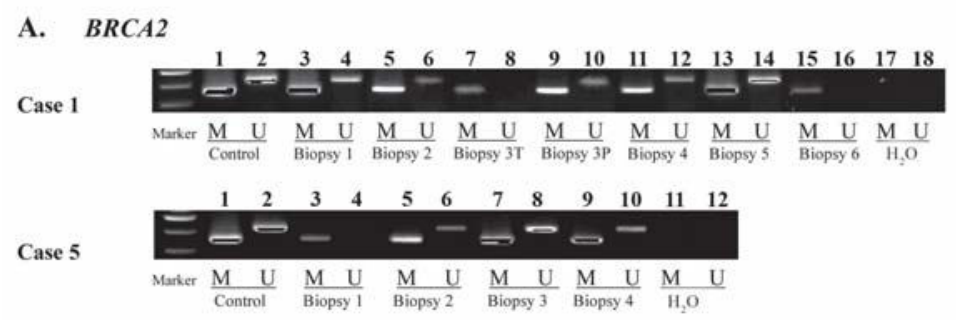

B. $A P C$

Case 1
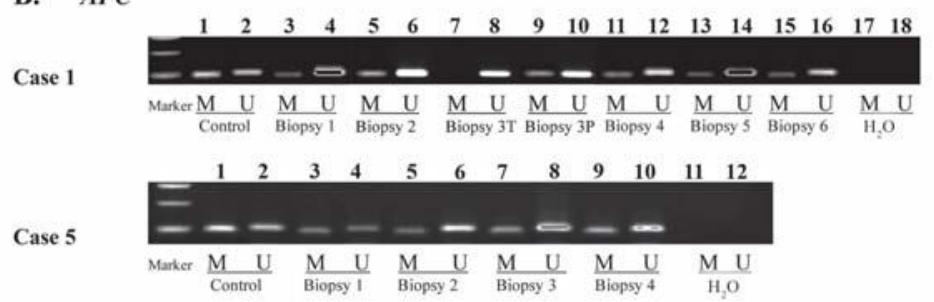

C. GSTPI

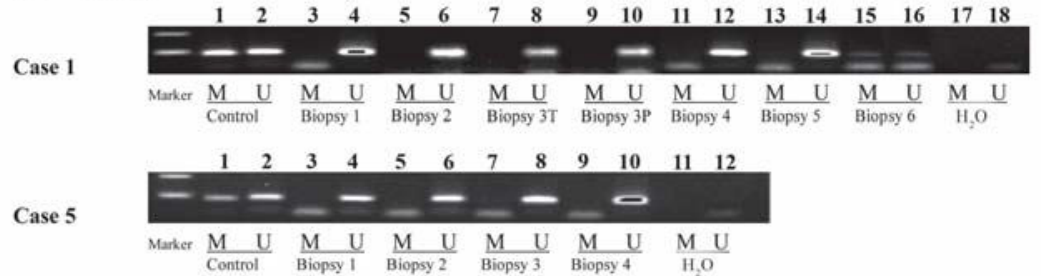

D. CDKN2A

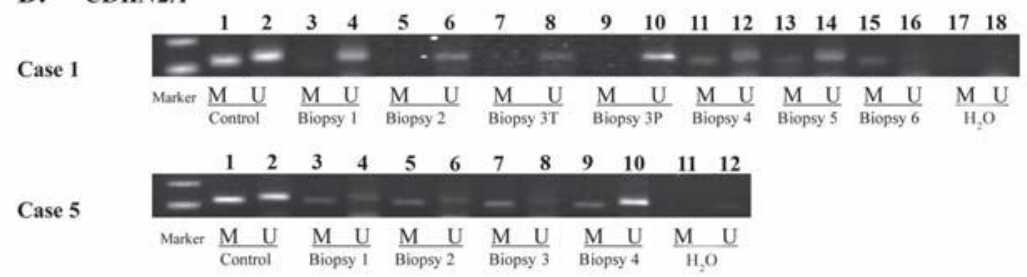

E. $C D K N 2 B$

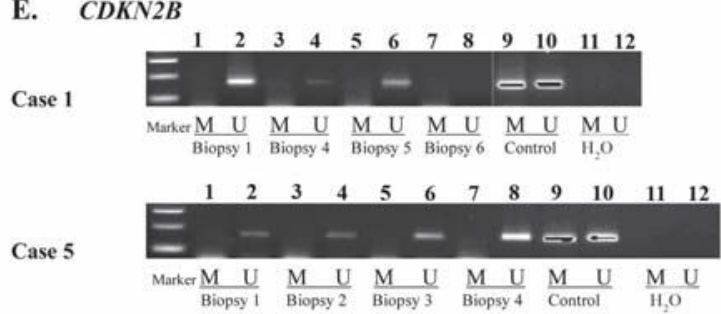

Figs 2A to E: Methylation specific PCR (MSP) for BRCA2, APC, GSTP1, CDKN2A and CDKN2B: A(BRCA2) Lanes 1 and 2: universal methylated and unmethylated controls; Case 1: Lanes 3-16 span biopsies 1-6. Note presence of methylated product in all biopsies. Lanes 17 and 18 : negative control. Case 5: Lanes 3-10 span biopsies 1-4. Note presence of methylated product in all biopsies. Lanes 11 and 12: negative control, $B(A P C)$ Lanes 1 and 2: universal methylated and unmethylated controls; Case 1: Lanes 3-16 span biopsies 1-6. Note presence of methylated product in biopsies 1, 2, 3P, 4, 5 and 6 (Table 3). Note absence of methylated product in biopsy 3T. Lanes 17 and 18: negative control. Case 5: Lanes 3-10 span biopsies 1-4. Note presence of methylated product in all biopsies. Lanes 11 and 12: negative control, C(GSTP1) Lanes 1 and 2: universal methylated and unmethylated controls; Case 1: Lanes 3-16 span biopsies 1-6. Note presence of methylated product in biopsy 6. Note absence of methylated product in biopsies 1-5. Lanes 17 and 18: negative control. Case 5: Lanes 3-10 span biopsies 1-4. Note absence of methylated product in all biopsies. Lanes 11 and 12: negative control, $D(C D K N 2 A)$ Lanes 1 and 2: universal methylated and unmethylated controls; Case 1: Lanes 3-16 span biopsies 1-6. Note presence of methylated product in biopsies 4, 5 and 6 . Note absence of methylated product in biopsies 1-3P. Lanes 17 and 18: negative control. Case 5: Lanes 3-10 span biopsies 1-4. Note presence of methylated product in all biopsies. Lanes 11 and 12: negative control, $E(C D K N 2 B)$ : Case 1: Lanes 1-8 span biopsies 1, 4-6. Note absence of methylated product in biopsies 1, 4 and 5. No reaction in biopsy 6 due to insufficient DNA. MSP was not performed on biopsies 2, 3T and 3P. Lanes 9 and 10: universal methylated and unmethylated controls. Lanes 11 and 12: negative control. Case 5: Lanes 1-8 span biopsies 1-4. Note absence of methylated product in all biopsies. Lanes 9 and 10: universal methylated and unmethylated controls. Lanes 11 and 12: negative control 
contributes to carcinogenesis in the oral region. $A P C$ inactivation as a result of promoter hypermethylation occurred in $25 \%$ of OSCC cell. ${ }^{38}$ Hypermethylation of $A P C$, observed in the initial and subsequent biopsies in RRP cases 1 and 5 is an early event and supports a monoclonal progression continuum to SCC.

$B R C A 2$ (Breast cancer 2, early onset) is a tumor suppressor gene whose mutations are strongly associated with an elevated risk of breast and ovarian cancers. ${ }^{39}$ Mutations in BRCA2 gene are associated with an increased risk of prostate, pancreas, stomach, melanoma, lung, and bladder cancers. ${ }^{40}$ Chromosome instability may be caused by failure in the repair of DNA double-strand breaks (DSB) ${ }^{41}$ and $B R C A 2$ is involved in maintaining genome stability. Aberrant promoter hypermethylation of $B R C A 2$ was detected in $42 \%$ of nonsmall cell lung cancer (NSCLC) compared to absent or low methylation in their matched normal lung tissue. ${ }^{42}$ In this study, aberrant methylation of $B R C A 2$ in the initial and subsequent transformation biopsies in RRP cases 1 and 5, similar to $A P C$, occurred early with retention in the progression continuum.

The study cohort, drawn from a multiethnic primary care patient population with nearly $40 \%$ AAs, revealed a nearly 5:1 predominance of CA with RP. CA race predilection for RP is supported by the Moore et al. ${ }^{21}$ study, which reported a 4:1 CA predominance for cohort subjects drawn from a mostly tertiary care patient population setting. We found a preponderance of male RP patients as compared to female RP (20 males: 5 females). This is a deviation from previous reports that indicate approximately equal gender distribution for RP. ${ }^{21,43}$

In RP, human papillomavirus types 6 and 11 account for 80 to $90 \%$ of RP. ${ }^{44}$ In our cohort, types 6 and 11 account for $96 \%$ of the cases with 22 cases positive for HPV-6 and 2 cases positive for HPV-11. HPV-11 appears to confer a more aggressive neoplastic phenotype than HPV-6 and is associated more often with atypia and frequent recurrence. ${ }^{45}$ Of the two RRP cases in this cohort positive for HPV-11, only case 5 progressed to SCC. Though the majority of RP harbor low-risk HPV 6 and 11, high-risk HPV types 16 and 18 have been reported and multiple HPV types were detected in $11.8 \%$ of RP. ${ }^{21}$ RRP case 1 with multiple HPV types (HPV-16 and 33 positive) progressed to SCC. High-risk HPV DNA alone may be sufficient to initiate tumorigenesis in the absence of traditional risk factors such as tobacco or alcohol use. ${ }^{21}$ Oncogenic HPV, particularly HPV-16, has been established as a causative agent for $25 \%$ of head and neck squamous cell carcinoma (HNSCC) ${ }^{20}$ and the development of laryngeal carcinoma is associated with HPV infection. ${ }^{19,20}$

MSP for the most part confirmed promoter hypermethylation detected by MS-MLPA. MSP did not confirm MS-MLPA methylation of $C D K N 2 B$ observed in case 1 and case 5 biopsies. While a distinct advantage of MS-MLPA is the ability to examine aberrant promoter methylation in multiple cancer genes in a single assay run, multiplex PCR of a large number of gene probes (22 unique genes) inherently encounters competitive amplification and detection algorithms may miss hypermethylation events that do not reach the threshold for detection. ${ }^{34}$ In contrast, MSP examines only one gene at a time ${ }^{18}$ and therefore, is more sensitive than MS-MLPA ${ }^{18}$ and is underscored by aberrant methylation of BRCA2 in case 1 and case 5 biopsies by MSP alone. In cases where MSP did not confirm MS-MLPA methylation, background noise presenting as spurious peaks may be a contributing factor. Spurious peaks (background noise) may be attributed to challenges posed to DNA from formalin-fixed tissue, the quality of which is dependent on tissue fixation variables. Regardless, MS-MLPA profiling of multiple genes for aberrantly methylated promoter regions is a valuable screening tool to determine frequency and pattern of promoter methylation in neoplasia. These epigenetic signatures, upon subsequent validation as diagnostic or prognostic biomarkers, can become reduced to a more definitive candidate gene panel of only a few key genes. The latter would be amenable to higher detection sensitivities using a targeted 3 or 4 MS-MLPA gene probe panel or by MSP alone.

Malignant transformation rates of benign laryngeal papillomas can range from 1.25 to $42.9 \%{ }^{4,5}$ and larger benign RP cohorts will be key to providing more accurate progression rates. Though this study is limited in its sample size ( 25 patients) and the number of cases that progressed to SCC ( 2 cases), it closely mirrors other larger study cohorts with similar transformation rates. ${ }^{21}$ In the two cases with progression to SCC, promoter methylation occurred as an early event and persisted in initial and subsequent biopsies for cases 1 and 5 with progression to cancer supporting an epigenetic monoclonal progression continuum to SCC.

The high frequency of DNA hypermethylation events in this study supports the utilization of gene silencing 
mechanisms as one of the driving forces behind the growth of laryngeal papillomas, reiterating DNA hypermethylation events as hallmarks of RP pathogenesis, some of which are initiating clonal alterations in the recurrence continuum in some RRP cases. ${ }^{14}$ Aberrant methylation of $B R C A 2, A P C$, $C D K N 2 A$ and $C D K N 2 B$, confirmed by MSP and detected in the initial and all subsequent transformation biopsies in RRP cases 1 and 5, appears to be an early event in the pathogenesis of laryngeal papillomatosis tracing a monoclonal progression continuum to SCC.

Epigenetic alterations identified in precancerous lesions with biomarker potential would have high clinical significance in risk assessment and early detection, and may also serve as molecular targets for chemopreventive interventions. Because promoter hypermethylation is potentially reversible, the molecules that regulate methylation status of DNA are considered promising targets for new cancer therapies.

\section{ACKNOWLEDGMENTS}

Drs. Stephen and Worsham had full access to all the data in the study and take responsibility for the integrity of the data and the accuracy of the data analysis. This study was supported by R01 NIH DE 15990 (Dr Worsham).

\section{REFERENCES}

1. Capper JW, Bailey CM, Michaels L. Squamous papillomas of the larynx in adults. A review of 63 cases. Clin Otolaryngol Allied Sci 1983;8(2):109-19.

2. Doyle DJ, Henderson LA, LeJeune FE (Jr) Miller RH. Changes in human papillomavirus typing of recurrent respiratory papillomatosis progressing to malignant neoplasm. Arch Otolaryngol Head Neck Surg 1994;120(11):1273-76.

3. Dedo HH, Yu KC. CO(2) laser treatment in 244 patients with respiratory papillomas. Laryngoscope 2001;111(9):1639-44.

4. Go C, Schwartz MR, Donovan DT. Molecular transformation of recurrent respiratory papillomatosis: Viral typing and p53 overexpression. Ann Otol Rhinol Laryngol 2003;112(4): 298-302.

5. Kossak-Glowczewska M. Spontaneous neoplastic transformation of laryngeal papilloma in adults. Otolaryngol Pol 1991;45(3):186-94.

6. Mounts P, Shah KV, Kashima H. Viral etiology of juvenileand adult-onset squamous papilloma of the larynx. Proc Natl Acad Sci USA 1982;79(17):5425-29.

7. Gabbott M, Cossart YE, Kan A, Konopka M, Chan R, Rose BR. Human papillomavirus and host variables as predictors of clinical course in patients with juvenile-onset recurrent respiratory papillomatosis. J Clin Microbiol 1997;35(12): 3098-103.
8. Gissmann L, Wolnik L, Ikenberg H, Koldovsky U, Schnurch HG, zur Hausen H. Human papillomavirus types 6 and 11 DNA sequences in genital and laryngeal papillomas and in some cervical cancers. Proc Natl Acad Sci USA 1983;80(2):560-63.

9. Penaloza-Plascencia M, Montoya-Fuentes H, Flores-Martinez SE, Fierro-Velasco FJ, Penaloza-Gonzalez JM, Sanchez-Corona J. Molecular identification of 7 human papillomavirus types in recurrent respiratory papillomatosis. Arch Otolaryngol Head and Neck Surg 2000;126(9):1119-23.

10. Hartley C, Hamilton J, Birzgalis AR, Farrington WT. Recurrent respiratory papillomatosis: The Manchester experience, 19741992. J Laryngol Otol 1994;108(3):226-29.

11. Lie ES, Karlsen F, Holm R. Presence of human papillomavirus in squamous cell laryngeal carcinomas. A study of thirty-nine cases using polymerase chain reaction and in situ hybridization. Acta Otolaryngol 1996;116(6):900-05.

12. Lele SM, Pou AM, Ventura K, Gatalica Z, Payne D. Molecular events in the progression of recurrent respiratory papillomatosis to carcinoma. Arch Pathol Lab Med 2002;126(10):1184-88.

13. Egger G, Liang G, Aparicio A, Jones PA. Epigenetics in human disease and prospects for epigenetic therapy. Nature 2004;429(6990):457-63.

14. Stephen JK, Vaught LE, Chen KM, et al. An epigenetically derived monoclonal origin for recurrent respiratory papillomatosis. Arch Otolaryngol Head and Neck Surg 2007;133(7): 684-92.

15. Raju U LM, Sethi S, Qureshi H, Wolman SR, Worsham, MJ. Molecular Classification of Breast Carcinoma In Situ. Current Genomics 2006;7(8):523-32.

16. Stephen JK, Vaught LE, Chen KM, et al. Epigenetic events underlie the pathogenesis of sinonasal papillomas. Mod Pathol 2007;20(10):1019-27.

17. Worsham MJ, Pals G, Schouten JP, et al. Delineating genetic pathways of disease progression in head and neck squamous cell carcinoma. Arch Otolaryngol Head Neck Surg 2003;129(7):702-08.

18. Chen K, Sawhney R, Khan M, et al. Methylation of multiple genes as diagnostic and therapeutic markers in primary Head and Neck Squamous Cell Carcinoma Arch Otolaryngol Head Neck Surg 2007;133(11):1131-38.

19. Uobe K, Masuno K, Fang YR, et al. Detection of HPV in Japanese and Chinese oral carcinomas by in situ PCR. Oral Oncol 2001;37(2):146-52.

20. Miller CS, Johnstone BM. Human papillomavirus as a risk factor for oral squamous cell carcinoma: A meta-analysis, 1982-1997. Oral Surg Oral Med Oral Pathol Oral Radiol Endod 2001;91(6):622-35.

21. Moore CE, Wiatrak BJ, McClatchey KD, et al. High-risk human papillomavirus types and squamous cell carcinoma in patients with respiratory papillomas. Otolaryngol Head Neck Surg 1999;120(5):698-705.

22. Rady PL, Schnadig VJ, Weiss RL, Hughes TK, Tyring SK. Malignant transformation of recurrent respiratory papillomatosis associated with integrated human papillomavirus type 11 DNA and mutation of p53. Laryngoscope 1998;108(5):735-40.

23. Baker AH, Zaltsman AB, George SJ, Newby AC. Divergent effects of tissue inhibitor of metalloproteinase-1, -2 , or -3 overexpression on rat vascular smooth muscle cell invasion, proliferation, and death in vitro. TIMP-3 promotes apoptosis. J Clin Invest 1998;101(6):1478-87. 
24. Qi JH, Ebrahem Q, Moore N, et al. A novel function for tissue inhibitor of metalloproteinases-3 (TIMP3): Inhibition of angiogenesis by blockage of VEGF binding to VEGF receptor2. Nat Med 2003;9(4):407-15.

25. van der Laan WH, Quax PH, Seemayer CA, et al. Cartilage degradation and invasion by rheumatoid synovial fibroblasts is inhibited by gene transfer of TIMP-1 and TIMP-3. Gene Ther 2003;10(3):234-42.

26. Mohammed FF, Smookler DS, Taylor SE, et al. Abnormal TNF activity in Timp3-/- mice leads to chronic hepatic inflammation and failure of liver regeneration. Nat Genet 2004;36(9):969-77.

27. Momparler RL, Bovenzi V. DNA methylation and cancer. J Cell Physiol 2000;183(2):145-54.

28. Esteller M, Corn PG, Baylin SB, Herman JG. A gene hypermethylation profile of human cancer. Cancer Res 2001;61(8):3225-29.

29. Bian YS, Osterheld MC, Fontolliet C, Bosman FT, Benhattar J. p16 inactivation by methylation of the CDKN2A promoter occurs early during neoplastic progression in Barrett's esophagus. Gastroenterology 2002;122(4):1113-21.

30. Eads CA, Lord RV, Wickramasinghe K, et al. Epigenetic patterns in the progression of esophageal adenocarcinoma. Cancer Res 2001;61(8):3410-18.

31. Worsham MJ, Chen KM, Tiwari N, et al. Fine-mapping loss of gene architecture at the CDKN2B (p15INK4b), CDKN2A (p14ARF, p16INK4a), and MTAP genes in head and neck squamous cell carcinoma. Arch Otolaryngol Head Neck Surg 2006;132(4):409-15.

32. Danahey DG, Tobin EJ, Schuller DE, Bier-Laning CM, Weghorst CM, Lang JC. p16 mutation frequency and clinical correlation in head and neck cancer. Acta Otolaryngol 1999;119(2):285-88.

33. Lydiatt WM, Davidson BJ, Schantz SP, Caruana S, Chaganti RS. 9p21 deletion correlates with recurrence in head and neck cancer. Head Neck 1998;20(2):113-18.

34. Worsham MJ, Chen KM, Meduri V, et al. Epigenetic events of disease progression in head and neck squamous cell carcinoma. Arch Otolaryngol Head Neck Surg 2006;132(6):668-77.
35. Shintani S, Nakahara Y, Mihara M, Ueyama Y, Matsumura T. Inactivation of the p14(ARF), p15(INK4B) and p16(INK4A) genes is a frequent event in human oral squamous cell carcinomas. Oral Oncol 2001;37(6):498-504.

36. Yeh KT, Chang JG, Lin TH, et al. Epigenetic changes of tumor suppressor genes, P15, P16, VHL and P53 in oral cancer. Oncol Rep 2003;10(3):659-63.

37. Wong TS, Tang KC, Kwong DL, et al. Differential gene methylation in undifferentiated nasopharyngeal carcinoma. Int J Oncol 2003;22(4):869-74.

38. Uesugi H, Uzawa K, Kawasaki K, et al. Status of reduced expression and hypermethylation of the APC tumor suppressor gene in human oral squamous cell carcinoma. Int J Mol Med 2005;15(4):597-602.

39. Ford D, Easton DF, Stratton M, et al. Genetic heterogeneity and penetrance analysis of the BRCA1 and BRCA2 genes in breast cancer families. The Breast Cancer Linkage Consortium. Am J Hum Genet 1998;62(3):676-89.

40. Cancer risks in BRCA2 mutation carriers. The Breast Cancer Linkage Consortium. J Natl Cancer Inst 1999;91(15):1310-16.

41. van Gent DC, Hoeijmakers JH, Kanaar R. Chromosomal stability and the DNA double-stranded break connection. Nat Rev Genet 2001;2(3):196-206.

42. Lee MN, Tseng RC, Hsu HS, et al. Epigenetic inactivation of the chromosomal stability control genes BRCA1, BRCA2, and XRCC5 in non-small cell lung cancer. Clin Cancer Res 2007;13(3):832-38.

43. Steinberg BM, Abramson AL. Laryngeal papillomas. Clin Dermatol 1985;3(4):130-38.

44. Duggan MA, Lim M, Gill MJ, Inoue M. HPV DNA typing of adult-onset respiratory papillomatosis. Laryngoscope 1990;100(6):639-42.

45. Rabah R, Sakr W, Thomas R, Lancaster WD, Gregoire L. Human papillomavirus type, proliferative activity, and p53: potential markers of aggressive papillomatosis. Arch Pathol Lab Med 2000;124(5):721-24. 